Volume $4 \cdot$ Nomor 3. • Juni 2021

Pege (Hal.) : $357-367$

(C) Universitas Pamulang

JL.Surya Kencana No.1 Pamulang, Tangerang Selatan - Banten

website. :

Telp. (021) 7412566, Fax (021) 7412491

http://www.openjournal.unpam.ac.id/index.php/JPK Email : jurnalmarketing.unpam@gmail.com

\title{
Marketing Strategy for Culinary MSMEs in Magelang City During the Covid-19 Pandemic
}

\author{
Nining Yulia ${ }^{1}$; Ivo Novitaningtyas ${ }^{2}$ \\ Universitas Tidar, Email: niningyulia99@gmail.com ; ivo.novitaningtyas@untidar.ac.id
}

\begin{abstract}
The Covid-19 pandemic had an impact on MSMEs sectors in Magelang City, one of them is culinary sector. The purpose of this study was to identify and describe the business condition of culinary MSMEs in Magelang City during the Covid-19 Pandemic, and also propose marketing strategy based on a SWOT analysis and marketing mix. This study used descriptive qualitative approach. Primary data were obtained from 30 samples of culinary MSMEs thourgh interview and observation. Data were analyzed based on statistic descriptive to describe the business condition and SWOT to propose the marketing strategy. The results recommend culinary MSMEs in Magelang city to improve product quality and product innovation, provide discounted prices, promote products through social media, and provide venues that comply qith health protocol standards. By implementing this marketing strategg, it is hoped that culinary MSMEs in Magelang city business will survive and can develop during the Covid-19 pandemic.
\end{abstract}

Keywords: culinary MSMEs; marketing mix; marketing strategy; SWOT 


\section{A. INTRODUCTION}

The Covid-19 pandemic that occurred globally had an impact on the MSME business in Indonesia, as well as in the Magelang City. One of the MSME businesses that is most affected is the food and beverage (culinary) sector (Amri, 2020). These impacts include a decrease in sales, difficulty in obtaining raw materials, closure of MSME businesses, and a reduction in workforce which causes an increase in unemployment (Hardilawati, 2020; Pakpahan, 2020). In fact, the existence of MSMEs is very beneficial for the economy. The roles of MSMEs include supporting economic growth, increasing job opportunities to reduce unemployment, and improving people's welfare (Sudaryanto, 2012). Based on these conditions, a marketing strategy is needed for culinary MSMEs in Magelang City in order to survive the pandemic and play a positive role in the economy.

Marketing strategy is one of the most important activities in a business. The marketing strategy can be described based on the 4P elements of the marketing mix which consists of product, price, promotion, and place (Benyamin, 2019; Kotler \& Keller, 2018). Products are all goods and services that can be purchased and consumed by consumers. Price described as the amount of money it takes to get some combination of the product and services. Promotion is a communication from sellers to buyers that aims to change the attitude and behavior of the buyers. Then, place focused on location where the business operates and how potential buyers can reach that location. The implementation of the appropriate marketing mix strategy has been proven to increase consumer buying interest in the product (Mulyati \& Afrinata, 2018). Thus, this study considers formulating a 4P marketing mix strategy for culinary MSMEs in Magelang City.

Moreover, previous researchers have used SWOT analysis to formulate marketing strategies (Hidayat \& Rahmat, 2018; Yadi \& Kasmiruddin, 2014). In addition, Winarto (2021) also emphasizes the importance of a SWOT analysis to formulate a survival strategy for MSMEs during a pandemic because it can classify primary data based on internal and external factors. Internal factors are analyzed based on their strengths and weaknesses. Meanwhile, external factors are analyzed based on opportunities and threats. SWOT analysis provides strategy formulations that can be applied by culinary MSMEs in Magelang City.

Based on the description of the phenomena and problems above, this study is needed to identify how the business conditions of culinary MSMEs in Magelang City. By knowing the condition of the business, what are the internal and external factors of the business, it is possible to formulate a 4P marketing mix marketing strategy. The proposed marketing strategy is expected to have practical implications for culinary MSME players to be able to maintain their business during the Covid-19 Pandemic. If the business of culinary MSMEs can survive and develop, it is hoped that these conditions can have a positive effect on the economy.

\section{B. LITERATURE REVIEW}

\section{Marketing Strategy}

Marketing strategy has become a research topic that continues to be developed by researchers. The topic even attracted the attention of academics and scholars to implement community service programs to MSMEs by providing train and tutorials on marketing strategies (Bahrudin, Widdiyanti, \& Wahyono, 2020; Bukit et al., 2019; Garside et al., 2020; Hapsoro, Palupiningdyah, \& Slamet, 2019; Yunita \& Purwanto, 2020). Marketing strategy is a marketing mindset that is useful for achieving the marketing objectives of a company in which there are strategies regarding marketing targets, positioning, budget, and also the marketing mix (Kotler \& Keller, 2018). Meanwhile, the marketing strategy according to Tjiptono \& Chandra (2017) is a logic in marketing where companies have the expectation to 
create value for consumers and can achieve mutually beneficial relationships between the two. Marketing strategy also describes as a set of goals or objectives, and program that give direction to the marketer to increase the sales of products (Cay \& Irnawati, 2020).

\section{P Marketing Mix}

Marketing mix is a form of marketing that is useful for supporting one another by influencing consumers to buy the product or service being sold. According to Kotler \& Keller (2018) argues that the marketing mix itself is a group of tools in marketing consisting of Product, Price, Promotion, and Place. It is also known as the 4P marketing mix which is useful for achieving marketing goals in accordance with predetermined target markets. Products are all goods and services that can be purchased and consumed by consumers. Price described as the amount of money it takes to get some combination of the product and services. Promotion is a communication from sellers to buyers that aims to change the attitude and behavior of the buyers. Then, place focused on location where the business operates and how potential buyers can reach that location. Every business actor always tries to survive, compete, and also develop his business. Especially in the current conditions where MSMEs have been heavily impacted by the Covid-19 pandemic that has occurred recently. Therefore, business actors must be able to determine the right strategy for their marketing because the marketing activities carried out are directed at achieving the goal and also achieving the desired level of profit growth.

\section{SWOT Analysis}

SWOT analysis is a strategy formulation tool for various factors systematically to formulate a strategy from a study. This analysis is based on the logic that is useful for maximizing strengths and opportunities but at the same time minimizing weaknesses and threats (Ilhamuddin et al., 2018). Meanwhile, according to Noor (2014), the SWOT analysis itself is a plan that is useful for evaluating the strengths, opportunities, weaknesses, and threats in a project or business speculation. Strengths are the resources and capabilities possessed by the company. Strengths can be used by companies to face competitors and survive in the market through the company's advantages over competitors, while weaknesses are described as deficiencies or limitations that the company or organization has compared to competitors (Pearce \& Robinson, 2013). Opportunities are described as conditions that are expected to provide benefits to the company if they are utilized to realize them (Galavan, 2014). This opportunity factor is identified based on the company's external environmental conditions. Threats are described as conditions or circumstances that are not expected to be favorable for the company if they become reality (Galavan, 2014). The threat becomes an obstacle for the company's steps to compete or survive in the market. Threat factors are identified through observation of external environmental conditions. The SWOT analysis is not only used to formulate a company's competitive strategy but also can be used to focus on the formulation of a marketing strategy, especially based on the components of the marketing mix (Kumalasari, 2016; Lusiana \& Novitaningtyas, 2020).

\section{METHODOLOGY}

This study is qualitative descriptive. It is a study that aims to understand certain phenomena experienced by research subjects and describe them (Nazir, 2014). The descriptive method aims to provide a systematic description of the phenomena and facts found in the study (Nazir, 2014). The object of this study is culinary UMKM in Magelang City. The number of samples used is 30 MSMEs where this number has met the minimum number of samples in the study, which is between 30-500 (Sugiyono, 2013). The sampling method uses a convenience sampling method to obtain the most affordable sample in 
providing information (Suhartanto, 2014). This study used primary data obtained directly through interviews and observations during the period February - April 2021. The data were analyzed based on descriptive statistical analysis (mode) to describe business conditions and were analyzed based on SWOT to formulate a 4P marketing strategy.

Table 1 MSMEs Culinary in Magelang

\begin{tabular}{|c|c|}
\hline $\mathrm{NO}$ & MSMEs \\
\hline 1 & Mie Ayam Pak Sukur \\
\hline 2 & Warung Mbak Ning \\
\hline 3 & Angkringan Harno \\
\hline 4 & Warung Bu Endang \\
\hline 5 & Warung Makan Gemilang \\
\hline 6 & Bakso Pak Yatno \\
\hline 7 & Mie Ayam Pak Kino \\
\hline 8 & Es Pleret Nambangan \\
\hline 9 & Warung Makan Miroso \\
\hline 10 & Nasi Goreng Pak Lisun \\
\hline 11 & Pank Kebab \\
\hline 12 & Warung Makan Ayam Kampung \\
\hline 13 & Warung Pak Dipto \\
\hline 14 & Just Juice \\
\hline 15 & Warung Bakmi Pak Manto \\
\hline 16 & Es Laristar \\
\hline 17 & Warung Pawonku \\
\hline 18 & Angkringan Pak Godeg \\
\hline 19 & Roti Bakar Arjuna \\
\hline 20 & Camilan Mak sum \\
\hline 21 & Toko Getuk Trio Teglrejo \\
\hline 22 & Roti Bakar Serangkai \\
\hline 23 & Martabak Sahabat \\
\hline 24 & Angkringan Pak Suroto \\
\hline 25 & Sup Buah Cenat -Cenut \\
\hline 26 & Gudeg Bu Siti \\
\hline 27 & Ayam Goreng Salsa \\
\hline 28 & Martabak Pandawa \\
\hline 29 & Maratabak Manis Bintang \\
\hline 30 & Ayam bakar kholil \\
\hline
\end{tabular}




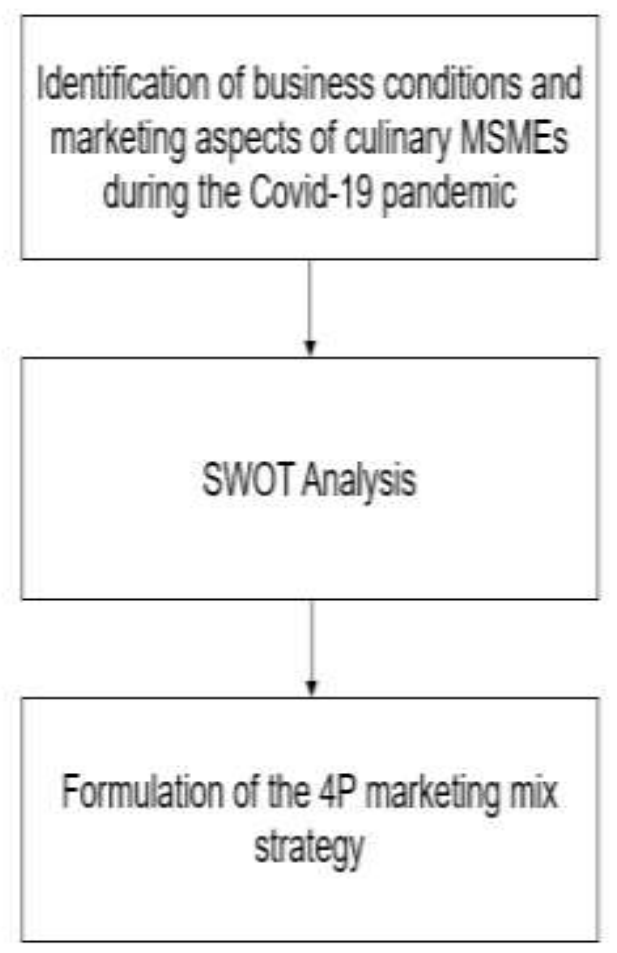

Figure 1. Conceptual Framework

\section{RESULT AND DISCUSSION}

\section{Business Conditions of Culinary MSMEs in Magelang City}

Business conditions are identified based on the level of sales, revenue, production activities, distribution activities, promotional activities, and product price bidding. The level of sales at culinary MSMEs in Magelang City has decreased. This result is in accordance with previous research which states that the decline in sales was also felt by almost all MSMEs in Indonesia, especially the culinary sector (Amri, 2020). Based on the results of observations that have been made, the condition of culinary MSMEs in Magelang City is classified as in poor condition where the percentage of sales decline that falls into the decline category is $25-50 \%$ as much as $56.3 \%$. The rate of decline is considered an alarming condition and must be addressed immediately. The delay in sales is due to several factors, especially due to the Covid-19 pandemic and the implementation of LargeScale Social Restrictions (called PSBB). This raises the risk that MSMEs will not be able to survive. 


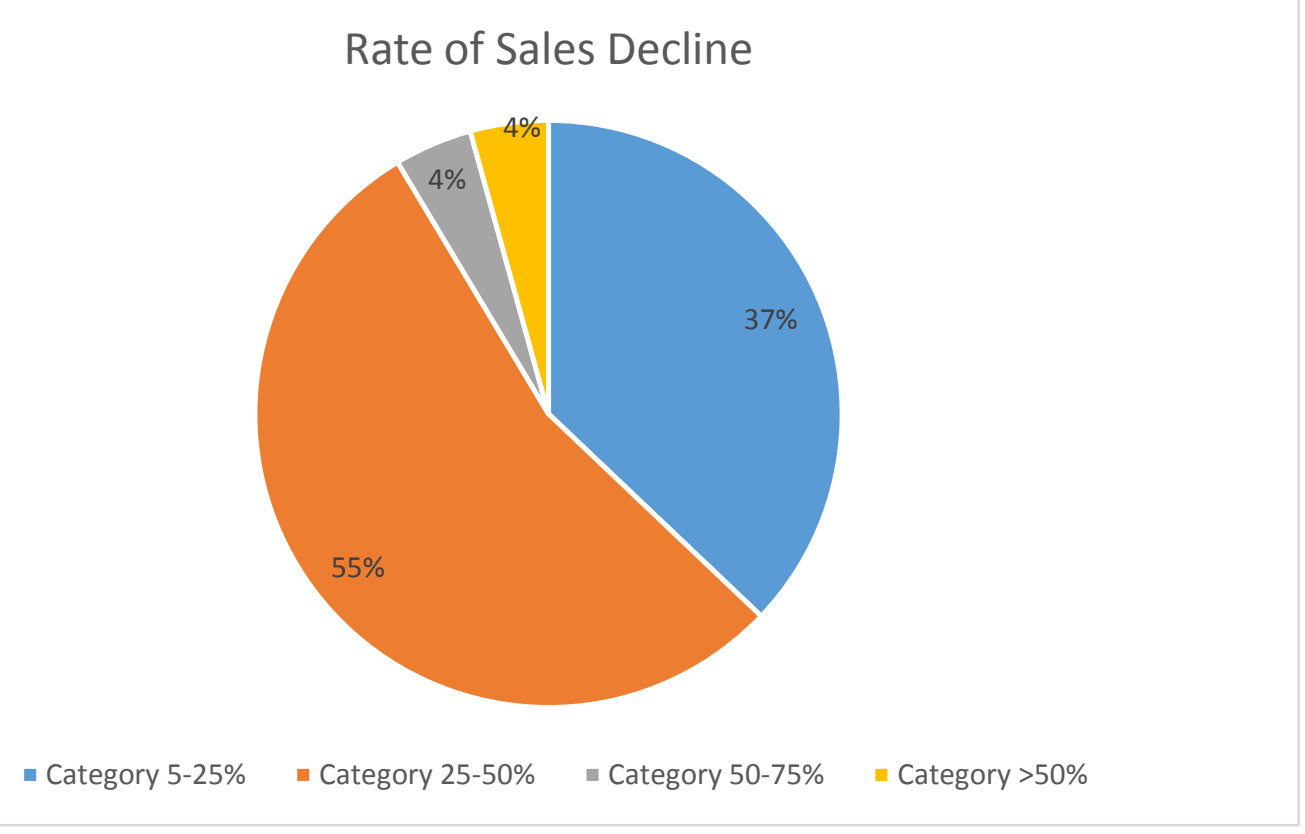

Figure 2. Rate of Sales Decline

The decline in the level of product sales will certainly have an impact on lowering income. The results of the observation show that as many as $40 \%$ of culinary MSMEs experience a decrease in income by $25-50 \%$. The figure for the decline in income is in a dire condition and must be addressed immediately. Therefore, culinary MSMEs must update their marketing strategies and adapt to the current pandemic conditions in order to survive.

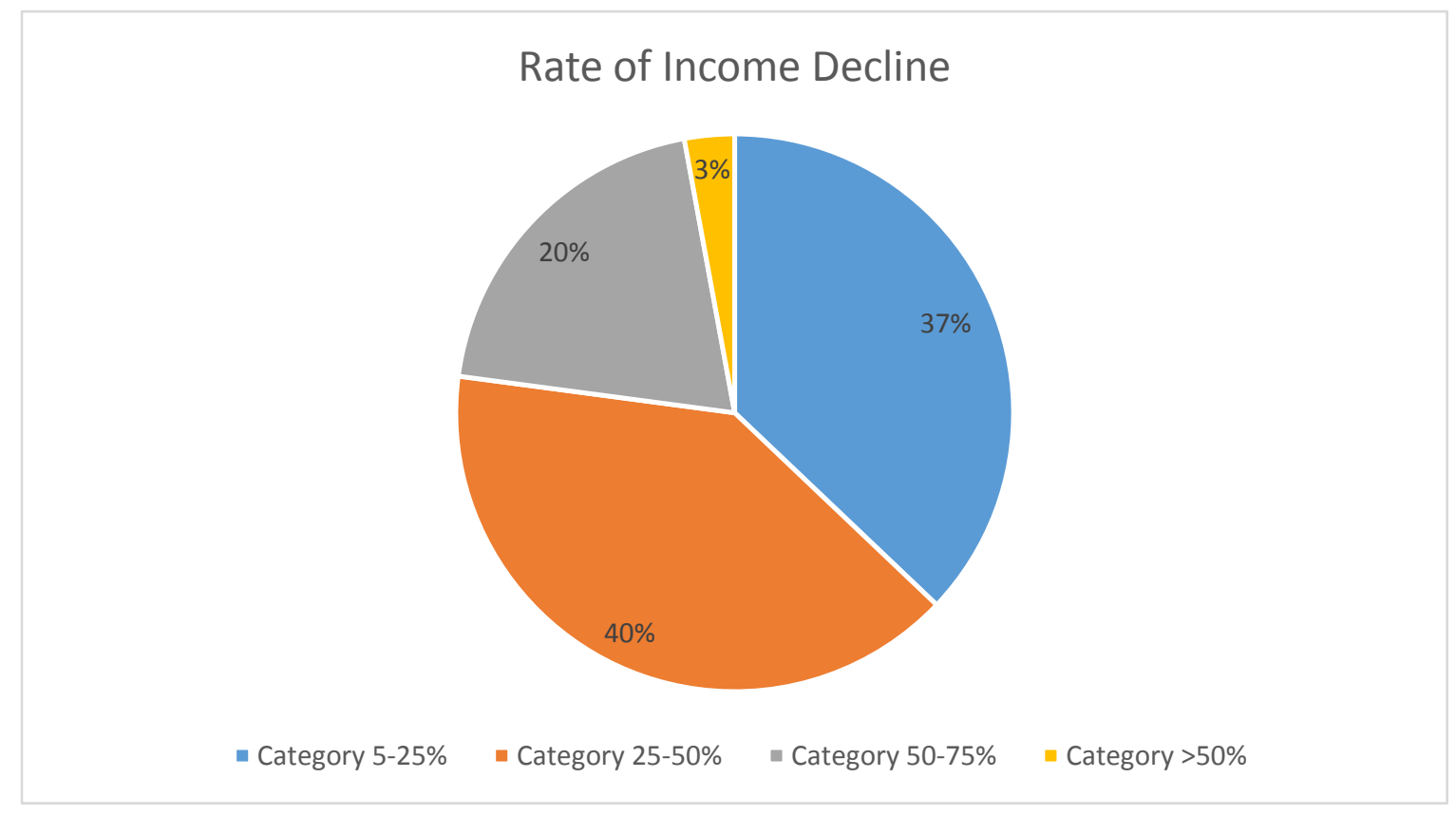

Figure 3. Rate of Income Decline 
Production activities must also be able to adapt to changing conditions that exist today. Running a business when the economy is affected by the Covid-19 pandemic is very difficult. Where a number of entrepreneurs are stricken with difficulties in achieving their targets. Based on the observation that has been obtained, $57.1 \%$ can produce smoothly and the remaining $42.9 \%$ are still constrained by the production process. However, fortunately most of the culinary MSMEs in Magelang City are still able to overcome their production activities to be able to run well despite the many obstacles that accompany them. The obstacles faced by culinary MSMEs are difficulties in obtaining raw materials for production, as well as an increase in operational costs and production costs due to PSBB constraints.

For the distribution or place aspect, the Covid-19 pandemic that is currently happening also has an impact on the distribution of culinary MSMEs in Magelang City. Where business activities must adapt to the new behavior of people who apply social and physical distancing. Currently, most places do not provide on-site meals, if they do provide, they must be able to apply health protocol rules and standard, such as maintaining a distance between one table and another. This makes business actors have to be smart to overcome these obstacles by changing their distribution strategies for the better to be able to cope with the current conditions in order to be able to survive. Based on a observation that has been obtained, $54.3 \%$ of culinary MSMEs in Magelang City are constrained by the distribution process of their products and the remaining $45.7 \%$ of MSMEs are able to overcome the obstacles that occur.

Then, for the promotion aspect, MSMEs must carry out promotions more often than before under normal conditions. Entrepreneurs also find it difficult to find the right marketing method to apply to their business. No exception to culinary MSMEs in Magelang City where not all of them are able to take full advantage of social media for their promotional media. Based on the observation that has been obtained, most of the culinary MSMEs in Magelang City experience problems in the promotion process. Where as many as $54.3 \%$ of MSMEs were constrained by their promotion process and the remaining $45.7 \%$ were able to overcome these promotion problem. Moreover, most of the MSMEs also have not utilized social media optimally for their business promotion media, where as many as $62.9 \%$ of MSMEs have not utilized social media optimally and only $37.1 \%$ have used it properly.

Most of the price offers for culinary MSMEs in Magelang City have not changed. The price of the products they offer to consumers is still the same as the price they offered before the Covid-19 pandemic. This is also an obstacle in increasing income in their business because they have not implemented a promo or discount strategy on certain days to attract consumer interest. Based on observations, around $80 \%$ of culinary MSMEs in Magelang City still apply prices long before the Covid-19 pandemic and the remaining $20 \%$ have implemented promo or discount strategies in their business.

\section{SWOT Analysis}

Data related to internal factors (strength, weaknesses), and external factors (opportunities, threats) obtained based on observations and interviews with entrepreneurs of culinary MSMEs and their consumers analyzed based on the following SWOT matrix. 
Table 1. SWOT

\begin{tabular}{|c|c|c|}
\hline Internal Factor & $\begin{array}{l}\text { Stenghts (S) } \\
\text { 1. Product taste good } \\
\text { 2. Product does not use } \\
\text { preservatives } \\
\text { 3. Products are processed } \\
\text { from quality raw } \\
\text { materials } \\
\text { 4. Affordable price }\end{array}$ & $\begin{array}{l}\text { Weaknesess (W) } \\
\text { 1. Less product innovating } \\
\text { 2. Not all MSMEs offer } \\
\text { price promotions } \\
\text { 3. Difficulty in accessing } \\
\text { raw materials during } \\
\text { PSBB } \\
\text { 4. Not all MSMEs use } \\
\text { social media as } \\
\text { promotion tools } \\
\text { 5ot all MSMEs have } \\
\text { implemented healtf } \\
\text { protocols }\end{array}$ \\
\hline $\begin{array}{l}\text { Opportunities (O) } \\
\text { 1. Food and beverages } \\
\text { are the main needs of } \\
\text { consumers } \\
\text { 2. Trend of wanting to try } \\
\text { new or unique culinary } \\
\text { among consumers } \\
\text { 3. Trends in online } \\
\text { shopping and delivery } \\
\text { services among } \\
\text { consumers } \\
\text { 4. Most consumers have } \\
\text { social media }\end{array}$ & $\begin{array}{l}\text { SO Strategy } \\
\text { 1. Be consistent in } \\
\text { highlighting good } \\
\text { product quality and good } \\
\text { taste }\end{array}$ & $\begin{array}{l}\text { WO Strategy } \\
\text { 1. Do product innovation } \\
\text { according to consumer } \\
\text { needs } \\
\text { 2. Utilize social media as } \\
\text { a promotion tools }\end{array}$ \\
\hline $\begin{array}{l}\text { Threats (T) } \\
\text { 1. Price competition with } \\
\text { competitor } \\
\text { 2. PSBB policies and } \\
\text { health protocols } \\
\text { 3. Changes in consumer } \\
\text { behavior during a } \\
\text { pandemic }\end{array}$ & $\begin{array}{l}\text { ST Strategy } \\
\text { 1. Processing products } \\
\text { according to standard } \\
\text { health protocols to } \\
\text { increase products } \\
\text { quality. }\end{array}$ & $\begin{array}{l}\text { WT Strategy } \\
\text { 1. Provide discount price } \\
\text { 2. Implement healt } \\
\text { protocol-based service } \\
\text { in their restaurant or } \\
\text { venue }\end{array}$ \\
\hline
\end{tabular}

\section{P Marketing Mix Strategy}

Based on the results of the SWOT analysis, there are several strategies that can be applied by culinary MSMEs in Magelang City. The strategy consists of improve product quality and product innovation (product), provide discounted prices (prices), promote products through social media (promotion), and provide venues that comply qith health protocol standards (place).

The products offered by culinary MSMEs in Magelang City are very diverse, such as food, drinks, and various snacks and other typical Magelang traditional food and beverage. However, among the various existing products, most of the products are less innovative in the product menu they offer. In the current conditions of the Covid-19 pandemic, it is better if MSMEs actors update their product strategy by always innovating regularly, maintaining 
good product quality, not using preservatives. One example of innovation that can be carried out is for example the getuk souvenir product added with ginger extract so that the nutritional content in the getuk increases and is also good for consumption in conditions such as the current Covid-19 pandemic.

Pricing in a business will determine the competitive position and affect the level of product sales. Pricing can also be a benchmark for consumers to see whether the price offered at culinary MSMEs is affordable or not. At culinary MSMEs in Magelang City, most of the culinary product prices offered are still the same as before the Covid-19 pandemic or most MSMEs have not given discounts or discounts on certain days. In current conditions, business actors should change their pricing strategy even though the price offered is affordable for consumers. Therefore, it is better to provide discounts on certain days in order to attract consumers and increase income as well as to maintain their business.

The types of promotion carried out by most of the culinary MSMEs in Magelang City are still not optimal. It is because only by personal selling or only with a few social media that have just been used for their promotional media. Therefore, it is better for business actors to change their promotional strategy by maximally utilizing all existing social media as a means of marketing products because online media itself is able to spread information faster than other media. It is also suitable with the condition of consumer where they have and use social media everyday. In current conditions, business actors should be more aggressive in conducting promotions by providing promotions in the form of product discounts on certain days in order to attract consumer interest and share this information by social media.

Some of the market segments that are the target of culinary MSMEs in Magelang City are families and teenagers. By targeting this segment in an era that is more advanced in today's technology, it will be able to attract more consumers because of assessment reviews and also a comfortable and instagramable place. However, due to the existence of a guarding distance policy in the current pandemic conditions, the strategy that can be used is to provide a safe distance between seats according to the standard. In addition, health protocol-based services and facilities are also needed, such as temperature checks, hand sanitizers, masks, and hand washing stations. By implementing this service, it is hoped that it can increase consumer trust and their buying interest so that product sales can be increased during a pandemic.

\section{E. CONCLUSION}

The current Covid-19 pandemic has a major impact on economic instability, especially affecting the culinary sector MSMEs. Where culinary business actors experience a decrease in income and sales due to social distancing policies that reduce consumer activity. Therefore, updating and adapting marketing strategies based on the 4P marketing mix is needed so that culinary MSMEs can survive.Penulisan simpulan ditulis dalam bentuk paragraf mengalir. The results showed that the marketing strategy can be formulated through SWOT analysis and the 4P marketing mix. The marketing strategies that can be done to increase sales and income of culinary MSMEs in Magelang City include product strategy by always innovating regularly, maintaining product quality, not using preservatives, and carrying out a health protocol-based production process. The pricing strategy is done by changing the selling price before the pandemic to the selling price during the pandemic, and also with a strategy of providing discounts and promos. The promotion strategy is carried out more aggressively in promoting and also maximizing the use of all social media as a tools for product promotion. For the place strategy, by implementing health protocol rules or standard so that the product distribution process to consumer is not disrupted and consumers are comfortable in making product purchases. By 
implementing this marketing strategy, it is hoped that culinary MSMEs in Magelang City can increase sales of their products so that they can survive during a pandemic. Furthermore, this study provides practical implications for culinary MSME owners in other areas to implement the proposed marketing strategy, and provides theoretical contributions as a reference in developing a marketing strategy based on a SWOT analysis. However, this study has a limitation because it only uses one analytical tool to formulate a strategy. Further research can develop based on other strategic formulation tools such as the business model canvas, or develop quantitative research to test the effect of the marketing mix on increasing sales of culinary MSME products in other areas.

\section{REFERENCE}

Amri, A. (2020). Dampak Covid-19 Terhadap UMKM di Indonesia. Jurnal Brand, 2(1), 147153. Retrieved from https://www.academia.edu/42672824/Dampak_Covid19_Terhadap_UMKM_di_Indonesia

Bahrudin, A., Widdiyanti, \& Wahyono. (2020). Pemberdayaan Masyarakat Melalui Pengembangan Desain Produk ANyaman Mansiang di Jorong Taratak Nagari Kubang Kecamatan Guguak, Kabupaten Limapuluh Kita. JPPM (Jurnal Pengabdian Dan Pemberdayaan Masyarakat), 4(1).

Benyamin, A. P. (2019). Strategi Bauran Pemasaran (Marketing Mix Strategy) di Pasarkita Pamulang. Jurnal Pemasaran Kompetitif, 2(3), 1-9. https://doi.org/10.32493/jpkpk.v2i3.2836

Bukit, F. R. A., A.S, G. G., Irvan, I., \& Fahmi, F. (2019). Pembuatan Website Katalog Produk UMKM Untuk Pengembangan Pemasaran dan Promosi Produk Kuliner. JPPM (Jurnal Pengabdian Dan Pemberdayaan Masyarakat), 3(2), 229. https://doi.org/10.30595/jppm.v3i2.4317

Cay, S., \& Irnawati, J. (2020). The Influence Of Marketing Strategy and Brand Community On MSME Sales In South Tangerang City. Jurnal Pemasaran Kompetitif, 4(1), 102114.

Galavan, R. (2014). Doing Business Strategy. Ireland: NuBooks.

Garside, A. K., Baroto, T., \& Gunarimba Waibo, O. R. (2020). Penguatan Aspek Produksi dan Pemasaran pada Usaha Keripik Singkong Mix Sayur. JPPM (Jurnal Pengabdian Dan Pemberdayaan Masyarakat), 4(1), 61. https://doi.org/10.30595/jppm.v0i0.4614

Hapsoro, B. B., Palupiningdyah, \& Slamet, A. (2019). Peran Digital Marketing sebagai Upaya Peningkatan Omset. Jurnal Pengabdian Masyarakat, 23(2), 117-120. https://doi.org/http://dx.doi.org/10.15294/abdimas.v23i2.17880

Hardilawati, W. laura. (2020). Strategi Bertahan UMKM di Tengah Pandemi Covid-19. Jurnal Akuntansi Dan Ekonomika, 10(1), 89-98. https://doi.org/10.37859/jae.v10i1.1934

Hidayat, R., \& Rahmat, R. (2018). Analisis SWOT Sebagai Dasar Keputusan Strategi Pemasaran Pada Perusahaan Server Pulsa Di Kota Batam: Studi Kasus Pada CV. Star Pratama. Journal of Applied Business Administration, 2(1), 94-108.

Ilhamuddin, H. M., Rusminah, R., Hilmiati, H., \& Ahyar, M. (2018). Strategi Pengembangan Industri Kreatif Sektor Kerajinan Perhiasan Mutiara Di Kota Mataram. Jmm Unram Master of Management Journal, 7(1), 58. https://doi.org/10.29303/jmm.v7i1.402

Kotler, P., \& Keller, K. L. (2018). Manajemen Pemasaran Edisi Kedua Belas Jilid 1 (12th 
ed.). Jakarta: Indeks.

Kumalasari, A. N. (2016). Perencanaan Strategi Promosi Melalui Analisis SWOT Pada Bisnis Delicy. PERFORMA:Jurnal Manajemen Dan Start-Up Bisnis, 1(2), 225-234.

Lesmana, R., Widodo, A. S., \& Sunardi, N. (2020). The Formation of Customer Loyalty From Brand Awareness and Perceived Quality through Brand Equity of Xiaomi Smartphone Users in South Tangerang. Jurnal Pemasaran Kompetitif, 4(1), 1-12.

Lesmana, R., Sunardi, N., Hastono, H., \& Widodo, A. S. (2021). Perceived Quality Membentuk Customer Loyalty via Brand Equity pada Pengguna Smartphone Merek Xiaomi di Tangerang Selatan. Jurnal Pemasaran Kompetitif, 4(2), 157-167.

Lusiana, I., \& Novitaningtyas, I. (2020). Strategi Promosi Aplikasi Motorku Express Berdasarkan Analisis SWOT: Studi Kasus Pada Astra Motor Kedungsari Magelang. Jurnal Bisnisman: Riset Bisnis Dan Manajemen, 2(2), 1-14.

Mulyati, Y., \& Afrinata, M. (2018). Analisis Pengaruh Strategi Bauran Pemasaran Terhadap Minat Berkunjung Kembali Pada Destinasi Wisata Pantai Carocok Painan Kabupaten Pesisir Selatan (Studi Kasus Pada Wisatawan Domestik). Jurnal Akuntansi, Ekonomi Dan Manajemen Bisnis, 6(2), 191-200.

Nazir, M. (2014). Metode Penelitian. Bogor: Ghalia Indonesia.

Noor, S. (2014). Penerapan Analisis SWOT Dalam Menentukan Strategi Pemasaran Daihatsu Luxio di Malang (Studi Kasus Pada PT. Astra International Tbk.-Daihatsu Malang). Jurnal INTEKNA, 16(2).

Pakpahan, A. K. (2020). Covid-19 Dan Implikasi Bagi Usaha Mikro, Kecil, Dan Menengah. Jurnal Ilmiah Hubungan Internasional, $0(0), \quad$ 59-64. https://doi.org/10.26593/jihi.v0i0.3870.59-64

Pearce, J. A., \& Robinson, R. B. (2013). Manajemen Strategis(Formulasi, Implementasi, dan Pengendalian). Jakarta: Salemba Empat.

Sudaryanto. (2012). Strategi Pemberdayaan UMKM Menghadapi Pasar Bebas ASEAN. Jurnal Ekonomi Akuntansi Dan Manajemen, 1(2).

Sugiyono. (2013). Metode Penelitian Bisnis (Pendekatan Kuantitatif, Kualitatif dan R\&D). Bandung: Penerbit Alfabeta.

Sunardi, N., \& Lesmana, R. (2020). Konsep Icepower (Wiramadu) sebagai Solusi Wirausaha menuju Desa Sejahtra Mandiri (DMS) pada Masa Pandemi Covid-19. JIMF (Jurnal Ilmiah Manajemen Forkamma), 4(1).

Suhartanto, D. (2014). Metode Riset Pemasaran. Bandung: Penerbit Alfabeta.

Tjiptono, F., \& Chandra, G. (2017). Pemasaran Strategik Edisi 3. Yogyakarta: Penerbit Andi.

Winarto, A. J. (2021). Analisis SWOT Sebagai Strategi Dalam Membantu Perekonomian UMKM Jasa KOnveksi @ANFCREATIVE.ID di Era Pandemi. Syntax Literate: Jurnal IImiah Indonesia, 6(1), 74-88.

Yadi, H., \& Kasmiruddin. (2014). Penerapan Analisis SWOT Manajemen Pemasaran Bisnis Developer (Studi: Perumusan Strategi Pemasaran PT. Sinar Mulya Sejahtera Pekanbaru). JOM FISIP, 1(2).

Yunita, A., \& Purwanto, H. (2020). Peningkatan Pemasaran Produk Kerajinan Bambu di Dusun Sanggrahan I, Desa Muntuk, Dlingo, Bantul. 